\title{
RADIOCARBON DATING OF THE TEMPLE OF THE MONKEY-THE NEXT STEP TOWARDS A COMPREHENSIVE ABSOLUTE CHRONOLOGY OF PACHACAMAC, PERU
}

\author{
Adam Michczyński ${ }^{1,2} \bullet$ Peter Eeckhout $^{3} \bullet$ Anna Pazdur $^{1} \bullet$ Jacek Pawlyta $^{1}$
}

\begin{abstract}
The ongoing Ychsma Project aims to shed light on the chronology and function of the late Prehispanic period at the well-known archaeological site of Pachacamac, Peru, through extensive archaeological research. The Temple of the Monkey is a special building that has been cleared, mapped, and excavated within the general framework of the study of "pyramids with ramps," the most common form of monumental architecture at the site. Through the application of radiocarbon measurements, it can be shown that the temple has been used for around $150 \mathrm{yr}$ and therefore is quite different from other pyramids with ramps previously studied (see Michczyński et al. 2003). Details of the temple, ${ }^{14} \mathrm{C}$ sample selection, and methodology, as well as results, are discussed in this paper. The research has allowed us to make significant advances in the current understanding of pyramids with ramps and the function of the site of Pachacamac as a whole.
\end{abstract}

\section{INTRODUCTION}

Pachacamac, one of the largest and most important archaeological sites in Peru, is located $30 \mathrm{~km}$ south of Lima and $\sim 0.5 \mathrm{~km}$ from the Pacific Ocean. It was an urban center, permanently inhabited probably from the first centuries AD until the Spanish conquest in AD 1535. Significant developments at the site took place in the Ychsma period (or Late Intermediate period, AD 900-1470), when Pachacamac became the religious center and the seat of rulers. During this period, a number of "pyramids with ramps" (defined below) were constructed.

Extensive research at Pachacamac has been carried out since 1999 as part of the Ychsma Project by a team led by Peter Eeckhout. The project has been designed to answer questions relating to the function, development, and influence of Pachacamac during the late Prehispanic periods. In 2003, the absolute chronology of Pyramid III at Pachacamac was defined and discussed (Michczyński et al. 2003). The study was based on 25 radiocarbon dates from the main structure of the Complex of Pyramid III: Pyramid IIIA and IIIB (Figure 1). A chronological model consisting of 7 successive steps was constructed on the basis of architecture and stylistic features, and the time intervals of the steps were estimated. Comparison of the results for Pyramid II and Pyramid III support the hypothesis of successive occupation and abandonment of the buildings, strengthening the hypothesis of a dynastic-like model of authority at the site (Eeckhout 1999a,b, 1999-2000, 2000). The results presented in this paper are the next step towards a comprehensive understanding of the chronology and functioning of Pachacamac.

\section{THE TEMPLE OF THE MONKEY}

"Pyramids with ramps" can be defined based on a series of recurrent specific features:

1. An orthogonal platform with one or more ascending terraces;

2. A series of rooms on the platform;

3. A rectangular patio at the foot of one of the platform's sides;

4. An access ramp between (1) and (3);

\footnotetext{
'Silesian University of Technology, Institute of Physics, Radiocarbon Laboratory, GADAM Centre of Excellence, Boleslawa Krzywoustego 2, 44-100 Gliwice, Poland.

${ }^{2}$ Corresponding author. Email: Adam.Michczynski@polsl.pl.

${ }^{3}$ Université Libre de Bruxelles, Département Histoire, Art et Archéologie (CP175), Av. F. Roosevelt 50, 1050 Brussels, Belgium.
} 


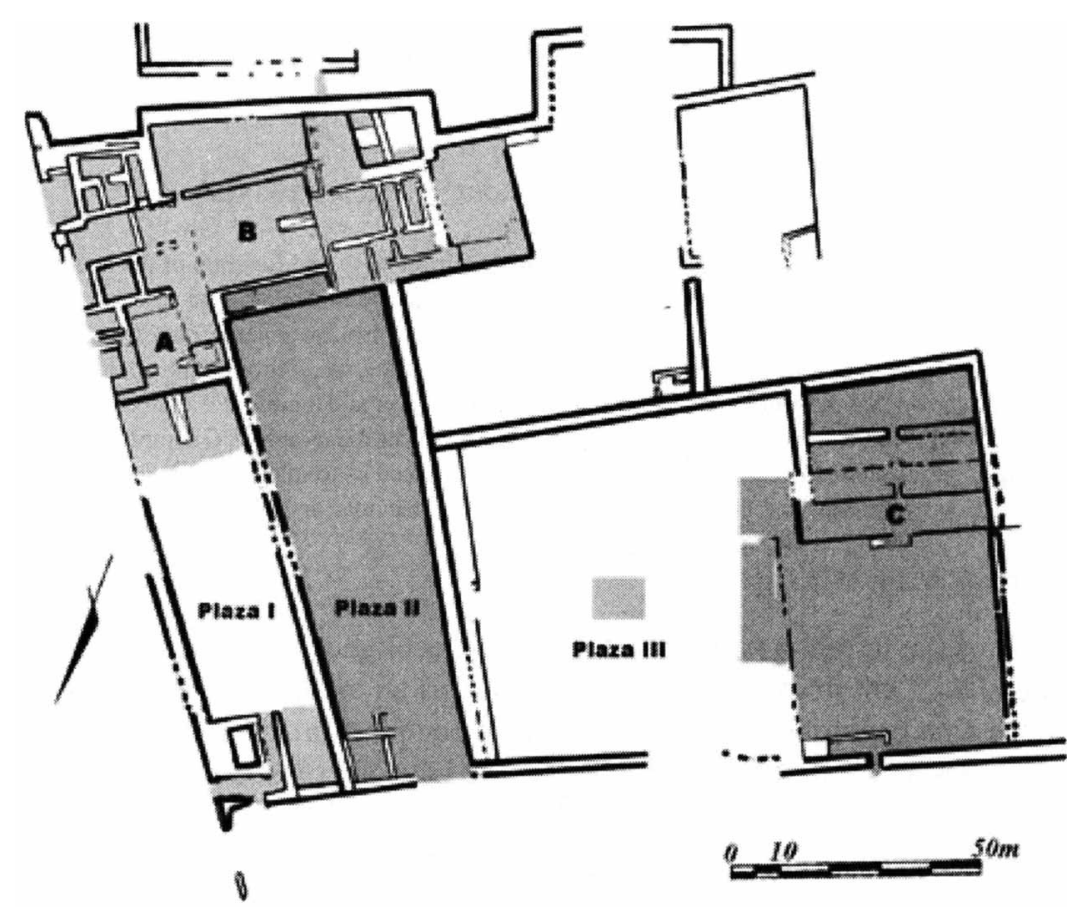

Figure 1 Plan of Pyramid III complex: A - Pyramid IIIA; B - Pyramid IIIB; C - Temple of the Monkey (Pyramid III-C).

5. A massive wall starting from the platform's sides and enclosing the patio;

6. A main entrance in the precinct, often provided with a system of access control (baffled door, watchtower, etc.).

Frequently, one finds attached to the terrace complex a series of sunken chambers, courtyards, and other secondary structures considered as annexes of the main building. A compound or pyramidal complex can be composed of one or several pyramids with ramps, such as in the case of Pyramid Complex III at Pachacamac, including pyramids III-A, III-B (discussed in Michczyński et al. 2003), and III-C (discussed here). Nevertheless, the excavations demonstrated there was no direct access between Pyramid III-C and the rest of the monumental complex. We can therefore deduce that Pyramid III-C functioned independently. Interestingly, other peculiarities show clear differences between A-B and C: a) architectural design; b) occupation patterns; and c) chronological evidence. Within the framework of this article, we will briefly review points (a) and (b), and will then concentrate on the dates and what they bring to the interpretation of the structures and the site itself.

Previous studies (Eeckhout 2003, 2004) of architectural design of pyramids with ramps at Pachacamac and the surrounding area showed that 3 main categories can be distinguished following differences in the arrangement of the features mentioned above: Type A - pyramids with a lateral ramp; Type $\mathrm{B}$ - pyramids with an offset ramp; Type $\mathrm{C}$ - pyramids with a central ramp. It is worth mentioning here that Type A is represented by a sole example at each of the sites where it is found. Type B is present in the lower Lurín Valley, but there is only 1 example at Pachacamac. Type $C$ is considered to be the "classical" model since it is the most prevalent; there are 18 such structures at Pachacamac. 
Pyramid III-C (Temple of the Monkey) pertains to Type A. It is composed of 3 main parts (from north to south):

1. A rectangular patio with a central baffled entrance and a narrow room on the one side and a lateral ramp on the other;

2. A 3-level roofed platform with benches and low-walled symmetrical subdivisions;

3. A large sunken room with a niche on its short eastern wall and a unique access staircase to the platform on the center of its long northern side (Figure 2).

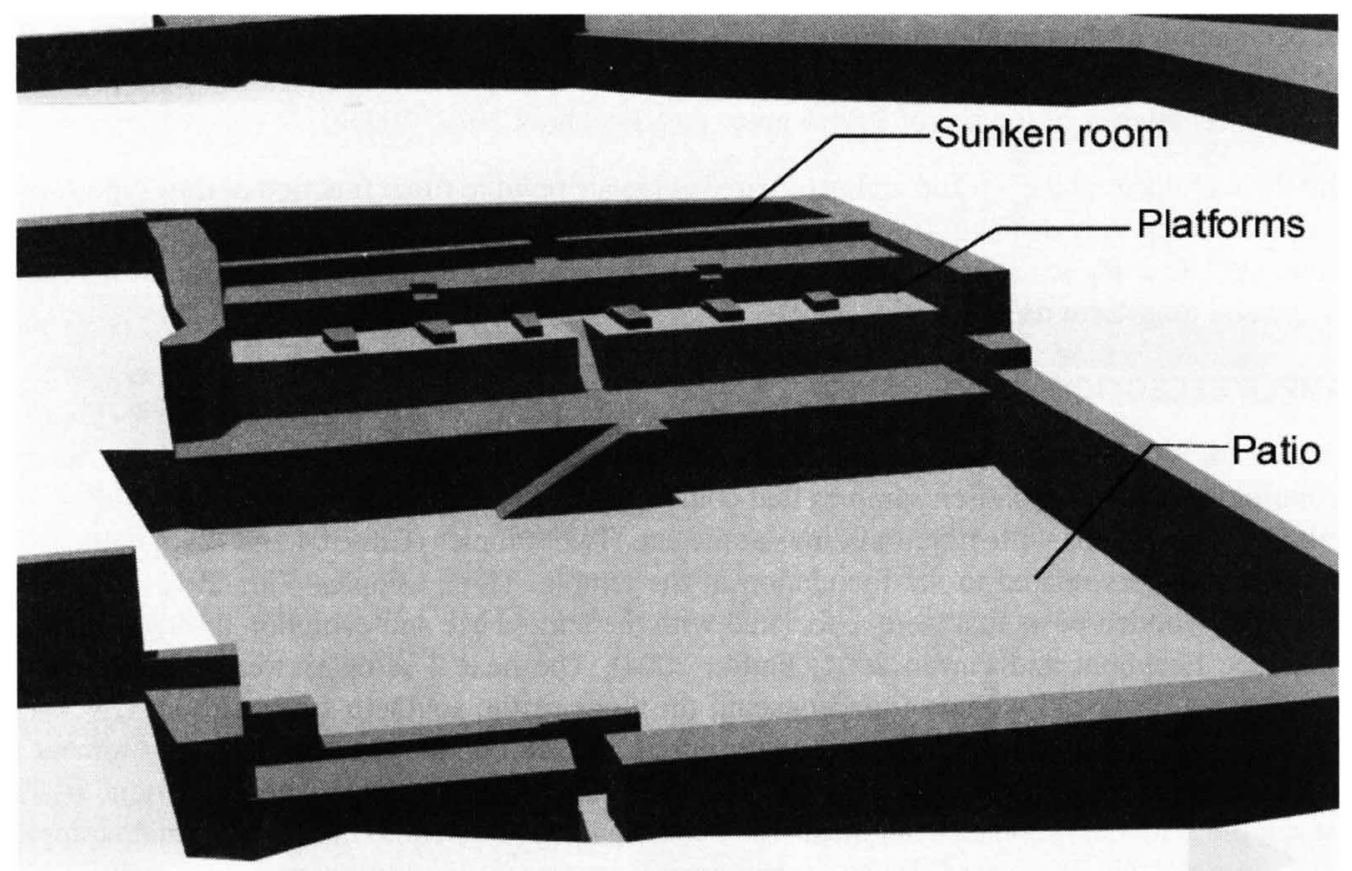

Figure 2 Three-dimensional reconstruction of the Temple of the Monkey

A huge, broad adobe wall totally encloses the whole structure as a precinct. As we shall see in the following, the specific architectural pattern described here perfectly fits with the finds made in each sector of the building and suggests a ritual function.

Indeed, the archaeological record provides strong evidence of ceremonial use. The patio was found clean, suggesting that it was not used for activities that leave remains, such as domestic or production material. This is very different from what one finds in Type $\mathrm{C}$ pyramids, for example, where the main patios were intensively used for food processing and consumption, guinea pig breeding, and daily craft production such as weaving (Eeckhout 1999-2000). On the platforms, we discovered a series of offerings including sacrificed animals, exotic seeds, and textiles, all related to the ceremonies that were performed there. The special design of this area includes a series of postholes forming a triangle just on the axis of the ramp climbing from the first to the second level. At the bottom of the central posthole, we found several offerings, including a child (probably sacrificed; Eeckhout and Owens, unpublished data) and the funerary bundle of a monkey (Cebus albifrons), which explains the name we have given to the building. On the second level of the platform, there is a clear 
bipartition of space, with empty rooms separated by low benches on the right side, and symmetrical rooms with a posthole for a probable wooden idol ${ }^{4}$ and several huge ceramic bowls sealed within the floors on the left side. The bowls were used for burning purposes and associated with different offerings including animals, exotic shells, and seeds as well as little metal sheets (Farfán 2004). Rope fragments were commonly found and are similar to those forming a net on the exterior layer of mummy bundles of the area. Numerous rope fragments have also been found in the sunken room on the southern part of the temple. Another series of offerings has been discovered there, including an impressive bundle containing almost 1000 Amazonian Nectandra sp. (ishpingo) seeds and the mummy of a woman (E20), sealed beneath the floor, probably corresponding to the end of the original occupation of the temple. In general terms, the temple has been interpreted as a specific structure dedicated to the last stage of preparation and sanctification for the mummies that were to be buried in the cemeteries of the site of Pachacamac (see Eeckhout 2002, 2005a).

Both the architectural design and archaeological evidence point to ritual function of this Type A pyramid, something very different from the palace-like occupation of Type $\mathrm{C}$ pyramids. As we shall see below, the ${ }^{14} \mathrm{C}$ evidence shows another interesting characteristic of the Temple of the Monkey: its old age and long-term use.

\section{SAMPLE SELECTION}

Samples for ${ }^{14} \mathrm{C}$ dating were selected in order to answer specific questions related to the temple chronology, so we have chosen samples that could help us to refine the history of the building and facilitate comparisons with other buildings at the site. Two samples (Gds-304 and -296) come from constructive layers related to the foundation of the temple. Three samples (Gds-291, -297, -298) come from wooden posts that were associated with the temple use and evolution through time (for details see Eeckhout and Farfán 2001; Farfán 2004). The next 2 samples were taken from the mummy of a 35-yr-old woman found beneath the floor of the southern sunken room (Eeckhout 2002). It was evident that it was a secondary burial, i.e, the bundle was buried at the moment of death and then taken out from his original tomb to be placed in the temple where we found it. The first sample (Gds-307) comes from inside the bundle and should help to date the original wrapping of the mummy, while sample Gds-306 comes from a reed wrapping placed over the bundle, which should then provide evidence about when this mummy was transferred and reburied within the Temple of the Monkey. The last 2 samples come from domestic reoccupation of the main courtyard (Gds-289) and a portion of the entrance lintel of the southern sunken room (Gds-295).

\section{METHODS}

Samples included in the analysis were dated in the Gliwice Radiocarbon Laboratory (lab code Gds) using the liquid scintillation technique. Measurements were carried out using a Quantulus $1220^{\mathrm{TM}}$ liquid scintillation spectrometer with standard sample pretreatment, benzene synthesis, and measurement procedures (Pawlyta et al. 1998). All ${ }^{14} \mathrm{C}$ dates were corrected for $\delta^{13} \mathrm{C}$ (Stuiver and Polach 1977) using an assumed value of $-25 \%$. Detailed information about samples and ${ }^{14} \mathrm{C}$ dates are presented in Table 1 . Conventional ${ }^{14} \mathrm{C}$ dates were calibrated using the OxCal v 3.10 (Bronk Ramsey 1995, 2001) calibration program and the IntCal04 calibration curve (Reimer et al. 2004). We decided not to use the SHCal04 calibration curve (McCormac et al. 2004) because the explored

\footnotetext{
${ }^{4}$ This hypothesis is supported by comparable evidence from the Painted Temple at Pachacamac (Paredes Botoni 1985) as well as the discovery of a wooden idol in the same building (Bueno Mendoza 1982; Jiménez Borja 1985) and early colonial accounts about wooden idols at the entrance of "demon temples" at the site (Jerez 1965:97).
} 


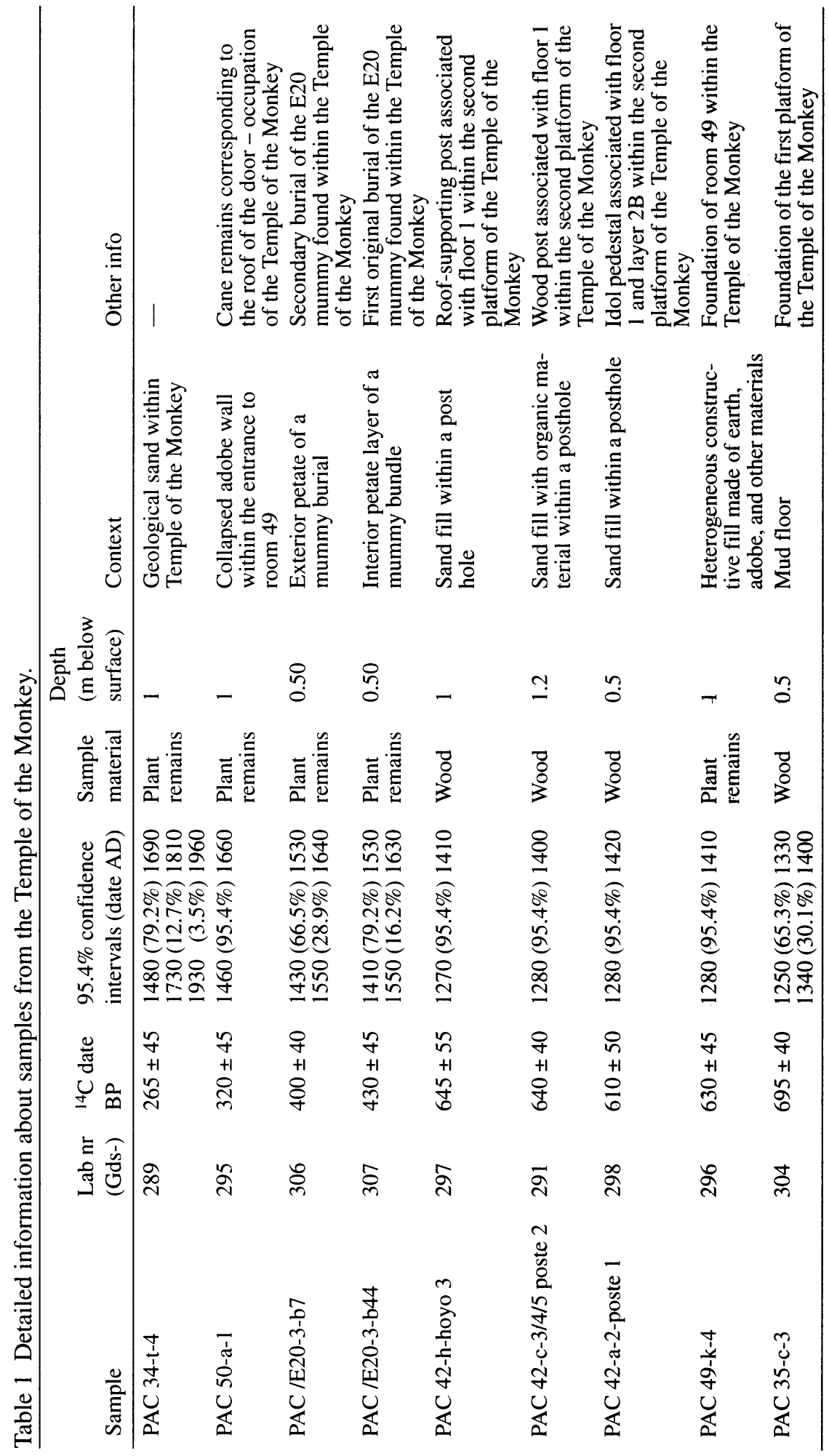


site is located close to the Intertropical Convergence Zone (at a latitude of $12^{\circ} \mathrm{S}$ ), while this curve is constructed based on data from latitudes $55-30^{\circ} \mathrm{S}$. Results of the calibration are shown in Figure 3.

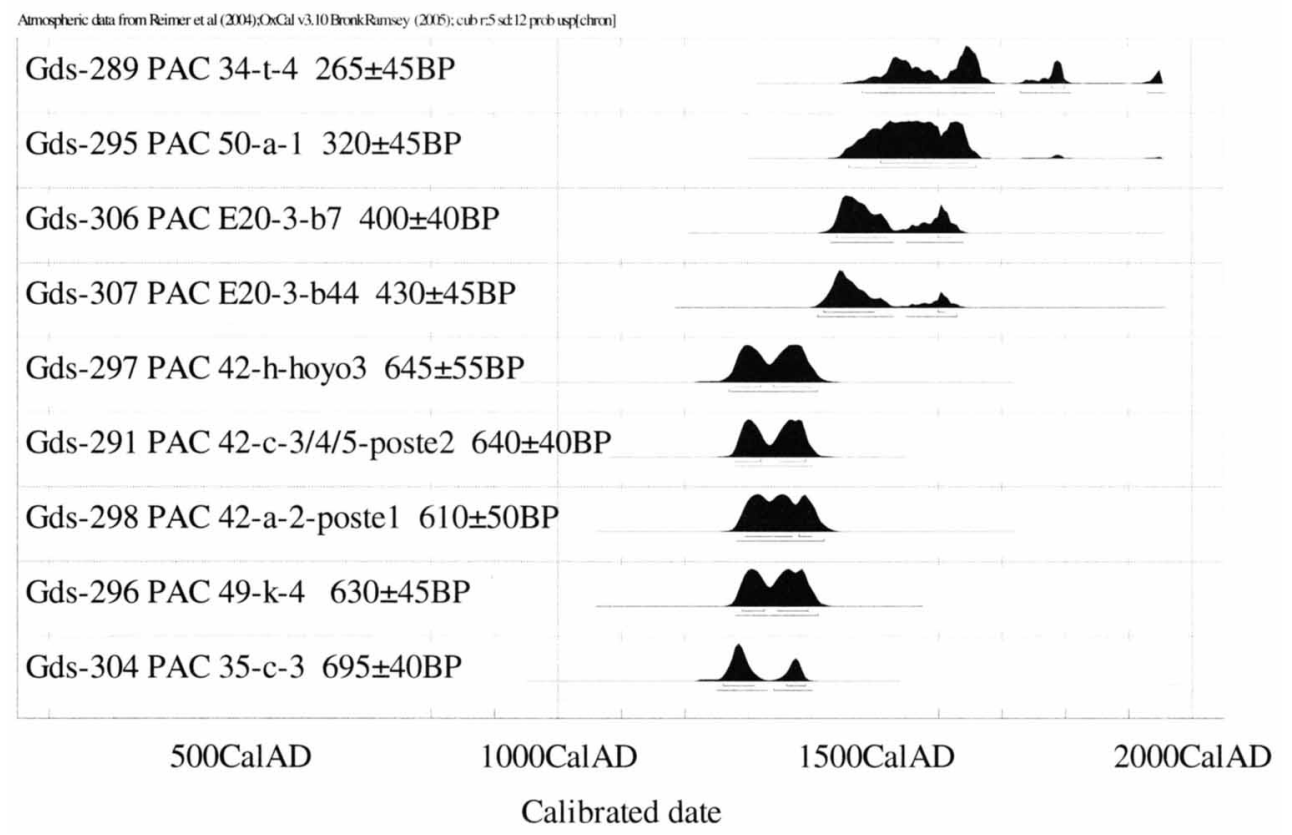

Figure 3 Calibration results of individual ${ }^{14} \mathrm{C}$ dates for samples from the Temple of the Monkey

\section{RESULTS AND DISCUSSION}

In order to estimate more precisely the calendar dates of studied objects and events, we used the OxCal v 3.10 calibration program to combine ${ }^{14} \mathrm{C}$ dates and other chronological information. We constructed a chronological model that allows for the following historical and archaeological prior data:

1. All calibrated dates should be older than the date of forced abandonment of the site during the Spanish conquest, which is known to be AD 1535 through historical sources.

2. Two groups of dates may be marked out from the set of all dates: the first group connected with the foundation and the first period of occupation of the temple (Gds-304, -296, -298, -291, and -297) and the second group connected with the E20 mummy (Gds-307, -306). Two dates (Gds$295,-289$ ) cannot be assigned to either of these groups. There is no prior relation between the first and the second group or between the groups and the unassigned dates.

3. The dates belonging to the first group may be divided into 2 subgroups corresponding to 2 succeeding phases of the chronology of the temple: the foundation of the temple (Gds-304, -296) and the first period of the temple occupation (Gds-298, -291, -297). We added to our model boundaries for the whole group and used them to find estimates of the beginning of the construction of the temple and the ending of the first period of occupation. There is no distinctly defined boundary between the foundation and the first period of occupation.

4. The date of the sample taken from the internal part of the mummy bundle (Gds-307, the first burial) should be older than the date of sample taken from external part (Gds-306, the second burial). 
The structure of the model and the posterior probability distributions of calibrated dates are presented in Figure 4. The overall agreement index of the model, as well as the agreement indices for every date, have values above the threshold (see Figure 4), which suggests that there is good concordance between the ${ }^{14} \mathrm{C}$ dates and the prior data of our model. Table 2 presents $68.2 \%$ and $95.4 \%$ confidence intervals of dates and events included in the model calculated based on the posterior distributions.

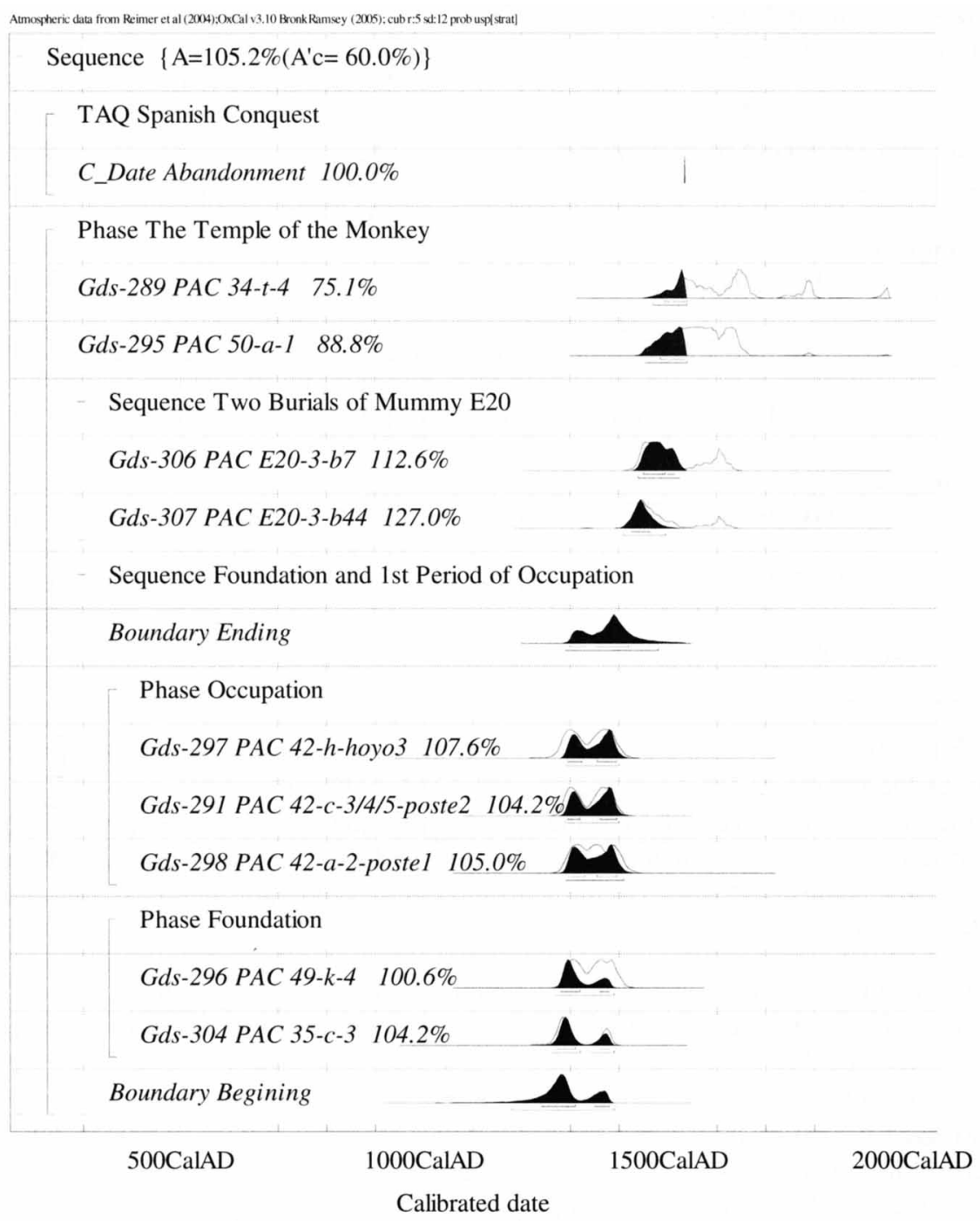

Figure 4 Structure of the assumed model of the chronology and the results of calibration (posterior distributions, agreement indices) obtained including the prior archaeological and historical data.

Figure 5a shows the posterior probability distributions of the dates belonging to the first group marked out in the model. The dates Gds-304 and -296 correspond to the foundation of the Temple of the Monkey, whereas the dates Gds-298, -291, and -297 are associated with the first period of temple occupation. Moreover, Figure 5a presents probability distributions of the initial (Beginning) 
Table 2 Confidence intervals of dates and events included in the model calculated basing on posterior distributions. All dates in AD.

\begin{tabular}{|c|c|c|c|c|}
\hline Element of model & Sample & Lab nr & $\begin{array}{l}68.2 \% \text { confidence } \\
\text { intervals }\end{array}$ & $\begin{array}{l}95.4 \% \text { confidence } \\
\text { intervals }\end{array}$ \\
\hline & PAC $34-\mathrm{t}-4$ & Gds-289 & $\begin{array}{l}1495(6.8 \%) 1505 \\
1510(61.4 \%) 1540\end{array}$ & $1470(95.4 \%) 1540$ \\
\hline & PAC 50-a-1 & Gds-295 & $1485(68.2 \%) 1535$ & $1455(95.4 \%) 1540$ \\
\hline \multicolumn{5}{|c|}{ Two burials of mummy E20 } \\
\hline 2nd burial & $\mathrm{PAC} / \mathrm{E} 20-3-\mathrm{b} 7$ & Gds-306 & $\begin{array}{lll}1450(58.6 \%) & 1495 \\
1500(9.6 \%) & 1515\end{array}$ & $1440(95.4 \%) 1525$ \\
\hline 1st burial & $\mathrm{PAC} / \mathrm{E} 20-3-\mathrm{b} 44$ & Gds-307 & $1425(68.2 \%) 1465$ & $1410(95.4 \%) 1495$ \\
\hline \multicolumn{5}{|c|}{ Foundation and 1st period of occupation } \\
\hline \multicolumn{2}{|c|}{ Boundary ending } & & $\begin{array}{l}1300(13.1 \%) 1330 \\
1350(55.1 \%) 1420\end{array}$ & $1290(95.4 \%) 1480$ \\
\hline \multicolumn{5}{|l|}{ Phase occupation } \\
\hline & PAC 42-h-hoyo 3 & Gds-297 & $\begin{array}{l}1295(28.6 \%) 1325 \\
1355(39.6 \%) 1395\end{array}$ & $1290(95.4 \%) 1400$ \\
\hline & PAC $42-\mathrm{c}-3 / 4 / 5$ poste 2 & Gds-291 & $\begin{array}{l}1295(27.9 \%) 1320 \\
1360(40.3 \%) 1395\end{array}$ & $1290(95.4 \%) 1400$ \\
\hline & PAC 42-a-2-poste 1 & Gds-298 & $\begin{array}{l}1295(31.7 \%) 1330 \\
1355(36.5 \%) 1395\end{array}$ & $1290(95.4 \%) 1410$ \\
\hline \multicolumn{5}{|l|}{ Phase foundation } \\
\hline & PAC 49-k-4 & Gds-296 & $\begin{array}{lll}1280(58.7 \%) & 1320 \\
1360(9.5 \%) & 1380\end{array}$ & $1270(95.4 \%) 1390$ \\
\hline & PAC 35-c-3 & Gds-304 & $\begin{array}{l}1270(57.9 \%) 1310 \\
1360(10.3 \%) 1380\end{array}$ & $\begin{array}{l}1260(70.9 \%) 1320 \\
1340(24.5 \%) 1390\end{array}$ \\
\hline Boundary beginn & ing & & $\begin{array}{l}1240(55.2 \%) 1310 \\
1350(13.0 \%) 1380\end{array}$ & $1180(95.4 \%) 1390$ \\
\hline
\end{tabular}

and final (Ending) boundary of the group. Based on the first of these, we may estimate the age of foundation of the temple as falling in the interval 1240-1310 with $55.2 \%$ probability. The dates related to the first period of occupation of the temple are in quite good concordance, and their probability distributions give us information about this time interval. The end of this period may be estimated by the final boundary (Ending) of the analyzed group, and it falls into the interval 1350-1420 with $55.1 \%$ probability.

In order to compare the results concerning the Temple of Monkey with the chronology of pyramids IIIA and IIIB from the previous study (Michczyński et al. 2003), we decided to recalibrate the latter using the IntCal04 calibration curve. Probability distributions of successive steps (phases) of the Pyramid III chronology calculated by means of the IntCal98 (Stuiver et al. 1998) calibration curve (which was used for calibration in the previous study) are presented in Figure 5 b by thin lines, whereas probability distributions calculated using IntCal04 are shown by thick lines. Furthermore, Figure 5b shows probability distributions for a group of $3{ }^{14} \mathrm{C}$ dates from Pyramid II (Michczyński et al. 2003) calculated using IntCal98 (thin line) and IntCal04 (thick line). It is notable that there is no significant difference between results obtained using IntCal98 and IntCal04; therefore, all conclusions drawn in our previous paper remain unchanged.

Comparison of the results of ${ }^{14} \mathrm{C}$ dating for the foundation and the first period of occupation of the Temple of the Monkey (see Figure 5a) and the results for pyramids IIIA and IIIB (Figure 5b) clearly shows that the Temple of Monkey is older than pyramids IIIA and IIIB. The age of its construction 


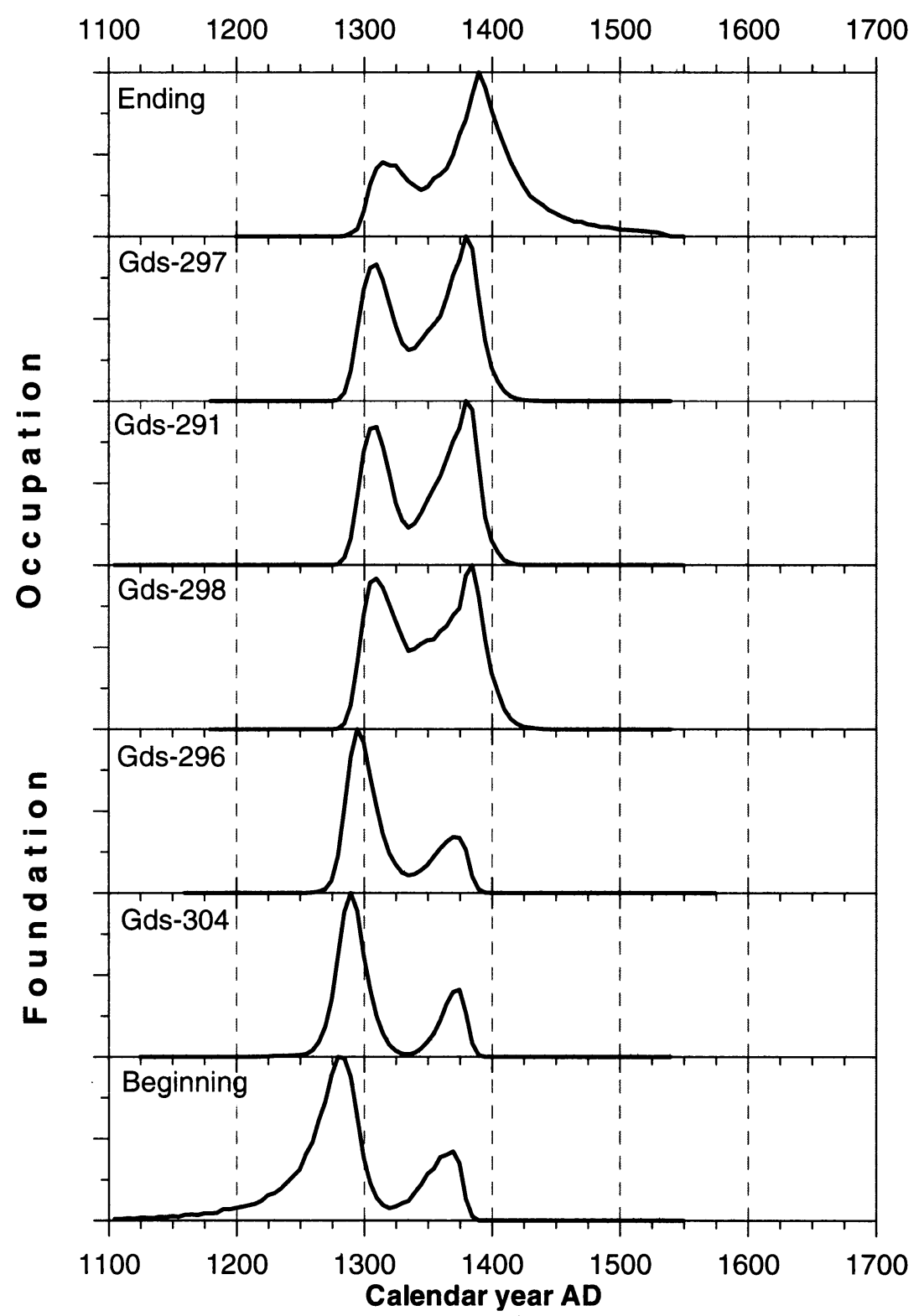

Figure 5a The posterior probability distributions of the dates belonging to the group connected with foundation and the first period of occupation of the Temple of the Monkey and the probability distributions of the initial (Beginning) and final (Ending) boundary of the group.

is similar to the age of occupation of Pyramid II, but it is also possible that the temple is even older than Pyramid II. Moreover, the results obtained for mummy E20 (discussed in the following) suggest that the temple was used also during the occupation of Pyramid IIIA.

The dates Gds-307 and -306 concern mummy E20 and they are almost identical (see Figure 3); however, archaeological evidence shows that the first date should be older because it dates a sample from inside of the mummy bundle (the first burial), while the second date concerns the external 


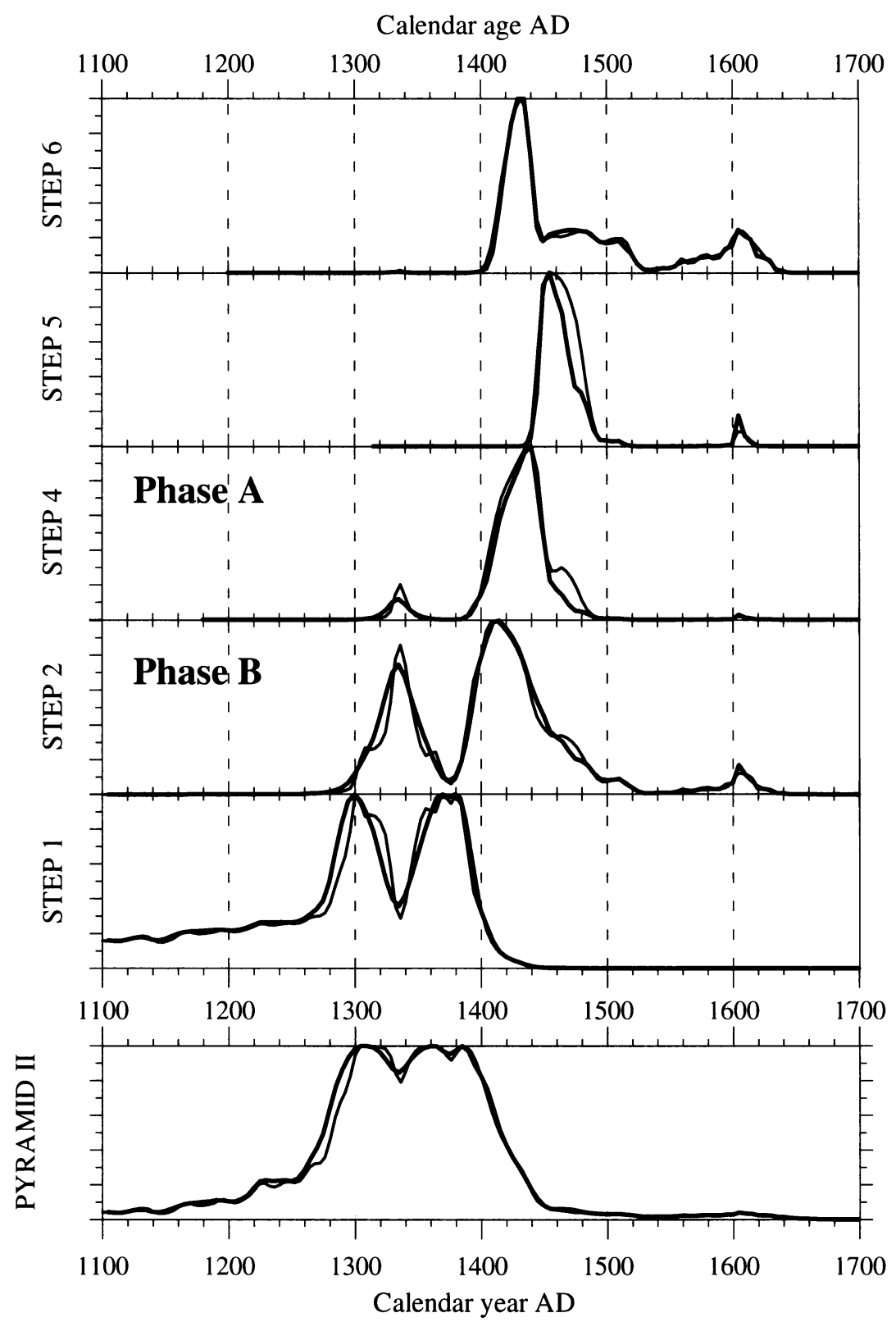

Figure 5b The absolute ${ }^{14} \mathrm{C}$ chronology of Pyramid III (STEP 1-6) and probability distribution of calendar age of 3 dates from Pyramid II. STEP 1 - refuse deposit; STEP 2 - construction and occupation of Pyramid IIIA; STEP 4 - construction and occupation of Pyramid IIIB; STEP 5 abandonment of Pyramid IIIA; STEP 6 - intrusive reoccupation (Michczyński et al. 2003). Probability distributions calculated using IntCal 98 are shown by thin lines, whereas distributions calculated using IntCal04 are thick lines.

wrapping and gives information about the second burial. This prior information, included in our model, allows us to estimate more precisely the age of the first and second burial of the mummy and the time span between burials. The posterior probability distributions of the calibrated dates of the 
first and the second burial and the probability distribution of the possible time span between burials are presented in Figure 6. The results (see also Table 2) show that the first burial took place in the period 1425-1465 (probability 68.2\%), while the second burial took place in the period 1450-1515 (probability $68.2 \%$ ). The time span between burials has a value smaller than $50 \mathrm{yr}$ (probability $68.2 \%$ ). The highest value of the probability distribution of the possible time span corresponds to a time span of $15 \mathrm{yr}$, whereas the mean value of time span comes to $30 \mathrm{yr}$. The last burial could match an important event in the history of the temple, such as voluntary abandonment and/or a change of function because of the Inca conquest (which probably occurs around AD 1470).
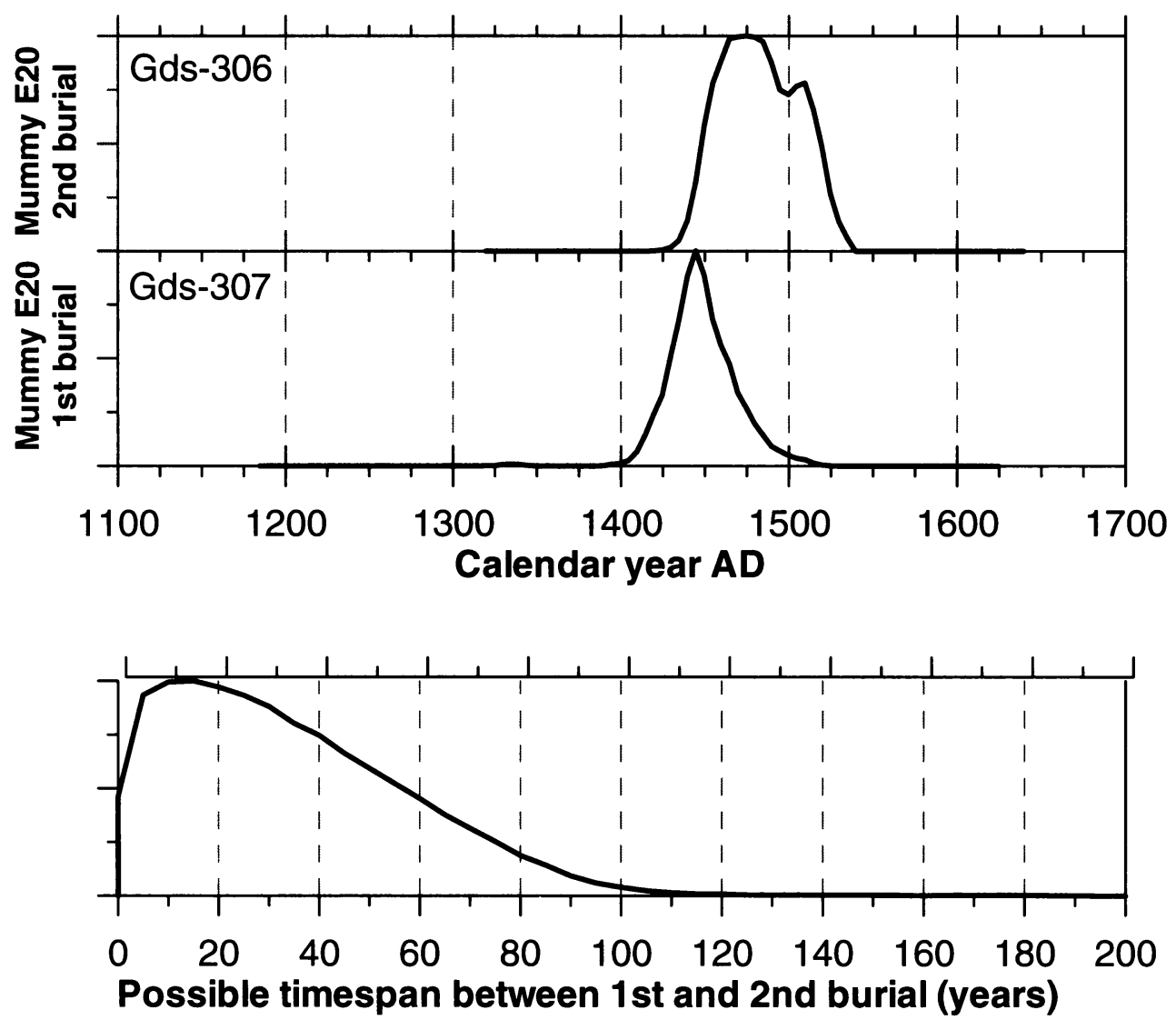

Figure 6 The posterior probability distributions of dates of the first and the second burial of mummy E20 and the probability distribution of the possible time span between burials.

The probability distribution of sample PAC 50-a-1 (Gds-295) is wide (see Figure 3), as the calibration curve is rather flat for the period between AD 1450-1600, but according to the model described above (see Figure 4) it is possible that the true sample age falls in the second half of the 15th century or in the beginning of the 16th century. This comment relates also to the probability distribution of the result obtained for sample PAC34-t-4 (Gds-289). These 2 results date a period of domestic and funerary ${ }^{5}$ reoccupation of the site, probably under Inca domination.

${ }^{5}$ Part of the Temple of the Monkey area has been reused for collective burials, unfortunately badly looted but clearly associated with Inca-related material (Eeckhout and Farfán 2001). 
${ }^{14} \mathrm{C}$ dating has provided quite a precise chronology for the Temple of the Monkey, suggesting the following: 1) a foundation in the second half of the 13th century AD; 2) a ceremonial occupation until at least the second half of the 15 th century $\mathrm{AD}$; and 3) a change of function during the Late Horizon (about 1475-1535). The Temple of the Monkey, along with the rest of the site, was totally abandoned at the time of the Spanish conquest in 1535.

\section{CONCLUSIONS}

The results show that the Temple of Monkey was built before pyramids IIIA and IIIB and that it was probably occupied longer than the neighboring pyramids II and III. This supports the hypothesis that this structure was separate from, and used for other purposes, than the rest of the Complex of Pyramid III. Indeed, the generational/dynastic model that we proposed for explaining the successive short-term occupation of Type $\mathrm{C}$ pyramids such as those mentioned does not fit Type A pyramids, such as the Temple of the Monkey, which seems to have been used continuously for about $150 \mathrm{yr}$. It is worth stressing once again that the Temple of the Monkey is the sole structure of its kind at Pachacamac. Interestingly, it is located in the Second Precinct of the site, a sector which contains almost all pyramids with ramps as well as streets, huge plazas, and cemeteries. The Second Precinct is separated by a wall from the Sacred Precinct, which contains the most sacred buildings of the settlement: 3 temples of different periods and an important cemetery, apparently for the burial of elites from the Middle Horizon (about AD 600-1000) until the Spanish conquest (AD 1535).

Our work and dating results then allow us to make 2 important statements. First, there is a clear relationship between form and function in the architecture at the site, i.e. formally similar buildings were used in a similar way. Type $C$ pyramids (those with a central ramp), as discussed in our previous paper (Michczyński et al. 2003), were palaces that functioned successively on a single generational basis (Eeckhout 2005b), while the Type A pyramid (with a lateral ramp) was a purely ceremonial structure that functioned on a multi-generational basis. Second, the presence of the Temple of the Monkey at the heart of a sector of the site containing mainly secular buildings suggests it had a special role. As a preliminary hypothesis, we propose that it was used for preparing mummies of the common people that were to be buried within the cemeteries of the Second Precinct, while elite mummies were prepared and buried within the Sacred Precinct. A clear social division of space at Pachacamac, which is attested in ethnohistoric accounts for the Inca period, would then find its roots deeper in time, probably within local traditions of the Late Intermediate period.

Finally, it is worth emphasizing the dating of mummy E20. Secondary burial is a fairly common practice in many societies of the past, and cases have been demonstrated thanks to the combination of archaeological data and the anthropological study of the remains (Crubézy et al. 2000). Nevertheless, as far as we know, the time span between the first and second burial is almost always impossible to determine. In this case, mummy E20 is exceptional since we could demonstrate that less than $\sim 50 \mathrm{yr}$ passed between death/first burial and second burial of this individual. Although it is of course very speculative to propose an interpretation for this, we note that this could fit within the ideology of the "ancestral cult" (Gélinas 1995; Salomon 1995; Duviols 2003). We hope that further research and discoveries will help us to better define such a practice and to understand its implications for social behavior at Pachacamac.

\section{ACKNOWLEDGMENTS}

Fieldwork and ${ }^{14} \mathrm{C}$ dating costs were sponsored by the Fonds de la Recherche Fondamentale Collective (Belgium), the Fonds National de la Recherche Scientifique (Belgium), the Centre de Recherches Archéologiques de l'Université Libre de Bruxelles, and a grant from the National Geographic 
Society Committee for Research and Exploration (Washington). We acknowledge the Instituto Nacional de Cultura del Perú for giving us the research permit at Pachacamac, and all the excavation staff who worked with us in the field. ${ }^{14} \mathrm{C}$ analyses were partially supported by statutory funds of the Silesian University of Technology BK-2004 and BK-2006.

\section{REFERENCES}

Bronk Ramsey C. 1995. Radiocarbon calibration and analysis of stratigraphy: the OxCal program. Radiocarbon 37(2):425-30.

Bronk Ramsey C. 2001. Development of the radiocarbon program. Radiocarbon 43(2A):355-63.

Bueno Mendoza A. 1982. El Antiguo Valle de Pachacamac: Espacio, Tiempo y Cultura. Lima: Editorial Los Pinos. 52 p. In Spanish.

Crubézy E, Massset C, Lorans E, Perrin F, Tranoy L, editors. 2000. L'Archéologie Funéraire. Paris: Editions Errance. 208 p. In French.

Duviols P. 2003. Cultura andina y represión. Procesos y visitas de idolotrías. Cajatambo, siglo XVII. Lima: Dondo Editorial de la Pontificia Universidad Católica del Perú-Instituto Francès de Estudios Andinos. 570 p.

Eeckhout P. 1999a. Pachacamac durant l'Intermédiaire récent. Etude d'un site monumental préhispanique de la Côte centrale du Pérou. British Archaeological Reports International Series, 747. Oxford: Hadrian Books Ltd. 504 p. In French.

Eeckhout P. 1999b. Pirámide con rampa nIII, Pachacámac. Nuevos datos, nuevas perspectivas. Boletín del Instituto Frances de Estudios Andinos 28(2):169-214. In Spanish.

Eeckhout P. 1999-2000. The Palaces of the Lords of Ychsma: an archaeological reappraisal of the function of pyramids with ramps at Pachacamac, central coast of Peru. Journal of American Archaeology 17-19: 217-54.

Eeckhout P. 2000. Pachacamac and the pyramids with ramps. Pre-Hispanic monuments and models on the central coast of Peru. Paper read at the Fifth Symposium of the Saintsbury Research Unit for the Arts of Africa, Oceania and the Americas: Recent Research on the Americas, University of East Anglia, Norwich.

Eeckhout P. 2002. Hallazgo y desenfardelamiento de un bulto funerario de Pachacamac. In: Solanilla Demestre V, editor. Actas de las II Jornadas Internacionales Sobre Textiles Precolombinos. Barcelona: Departament d'Art, Universitat Autónoma de Barcelona. p 135-52. In Spanish.

Eeckhout P. 2003. Ancient monuments and patterns of power at Pachacamac, central coast of Peru. Beiträge zur Allgemeine und Vergleichenden Archäologie 23: 139-82.

Eeckhout P. 2004. Pachacamac y el proyecto Ychsma (1999-2003). In: Eeckhout P, editor. Arqueología de la Costa Central del Perú en los Períodos Tardíos. Special volume of Boletín del Instituto Francés de Estudios Andinos 33(3):425-48. In Spanish.
Eeckhout P. 2005a. Uso ritual de semillas amazonicas en Pachacamac durante los períodos tardíos. Xama 15/ 18:110-26. Mendoza, Argentina. In Spanish.

Eeckhout P. 2005b. Ancient Peru's power elite. National Geographic Magazine 207(3):52-7.

Eeckhout P, Farfán C. 2001. Proyecto Ychsma, temporada 2000-2001. Final report to the Peruvian Instituto Nacional de Cultura, Lima. In Spanish.

Farfán C. 2004. Aspectos simbólicos de las pirámides con rampa. Ensayo interpretativo. In: Eeckhout P, editor. Arqueología de la Costa Central del Perú en los Períodos Tardíos. Special volume of Boletín del Instituto Francés de Estudios Andinos 33(3):449-64. In Spanish.

Gélinas C. 1995. Où les dieux-guerriers meurent sans périr. Le culte des ancêtres dans la société inca. $R \boldsymbol{e}$ cherche Amérindiennes au Québec 30(2):21-34. In French.

Jerez F. 1965 [1534]. Verdadera relación de la conquista del Perú y provincia del Cuzco llamada la Nueva Castilla conquistada por Francisco Pizarro. In: Le Riverend J, editor. Crónicas de la Conquista del Perú. Mexico City: Editorial Nueva Espana S.A. p 29-124.

Jiménez Borja A. 1985. Pachacamac. Boletín de Lima 38: 40-54. Lima. In Spanish.

McCormac FG, Hogg AG, Blackwell PG, Buck CE, Higham TFG, Reimer PJ. 2004. SHCal04 Southern Hemisphere calibration, 0-11.0 cal kyr BP. Radiocarbon 46(3): 1087-92.

Michczyński A, Eeckhout P, Pazdur A. 2003. ${ }^{14} \mathrm{C}$ absolute chronology of Pyramid III and the dynastic model at Pachacamac, Peru. Radiocarbon 45(1):59-74.

Paredes Botoni P. 1985. La Huaca Pintada o el Templo de Pachacamac. Boletín de Lima 41:70-7. Lima. In Spanish.

Pawlyta J, Pazdur A, Rakowski AZ, Miller BF, Harkness DD. 1998. Commissioning of a Quantulus $1220^{\mathrm{TM}}$ liquid scintillation beta spectrometer for measuring ${ }^{14} \mathrm{C}$ and ${ }^{3} \mathrm{H}$ at natural abundance levels. Radiocarbon 40(1):201-9.

Reimer PJ, Baillie MGL, Bard E, Bayliss A, Beck JW, Bertrand CJH, Blackwell PG, Buck CE, Burr GS, Cutler KB, Damon PE, Edwards RL, Fairbanks RG, Friedrich M, Guilderson TP, Hogg AG, Hughen KA, Kromer B, McCormac G, Manning S, Bronk Ramsey C, Reimer RW, Remmele S, Southon JR, Stuiver M, Talamo S, Taylor FW, van der Plicht J, Weyhenmeyer CE. 2004. IntCal04 terrestrial radiocarbon age calibration, 0-26 cal kyr BP. Radiocarbon 46(3): 1029-58.

Salomon F. 1995. "The Beautiful Grandparents": An- 
dean ancestor shrines and mortuary rituals as seen through colonial records. In: Dillehay TD, editor. Tombs for the Living: Andean Mortuary Practices. Washington, D.C.: Dumbarton Oaks Research Library and Collection. p 315-54.

Stuiver M, Polach HA. 1977. Discussion: reporting of
${ }^{14} \mathrm{C}$ data. Radiocarbon 19(3):355-63.

Stuiver M, Reimer PJ, Bard E, Beck JW, Burr GS, Hughen KA, Kromer B, McCormac G, van der Plicht J, Spurk M. 1998. IntCa198 radiocarbon age calibration, 24,000-0 cal BP. Radiocarbon 40(3): 1041-83. 